\title{
INDICATIONS FOR THE USE OF DRUGS IN THE TREATMENT OF PSYCHIATRIC DISORDERS
}

\author{
LiNford ReES, M.D., B.Sc., F.R.C.P., D.P.M. \\ Physician-in-Charge, Department of Psychological Medicine, St. Bartholomew's Hospital, London; Consultant Physician $\vec{\bigcirc}$ \\ the Maudsley and the Bethlem Royal Hospital, London
}

DuRING the past decade the drug treatment of psychiatric illness has advanced with remarkable rapidity.

The principal drugs concerned are those with predominant actions on higher mental and neurological functions and collectively referred to as psychotropic drugs. The main drugs used in practice can be classified into

(I) Anti-psychotic drugs (Neuroleptics).

(2) Anti-depression drugs.

(3) Anti-anxiety drugs.

The harbingers of the modern era of pharmacotherapy in psychiatry were reserpine and chlorpromazine.

Reserpine was rediscovered after use by Indian physicians many hundreds of years ago and chlorpromazine was first used by Laborit in France to facilitate low temperature surgery because of its suppressive action on the central and peripheral parts of both divisions of the autonomic nervous system. Later, chlorpromazine was used by Deniker, Delay and other members of the French school of psychiatry for treating psychiatric illnesses.

\section{Major Tranquillizers (Neuroleptics) Alkaloids derived from Rauwolfia serpentina}

These include reserpine, deserpedine and rescinamine.

They have a depressant action on hypothalamic structures and the reticular system, which is intimately concerned in determining degree of alertness. The effects of reserpine are tranquillization and reduction of activity. It differs from chlorpromazine in its autonomic effects as it stimulates parasympathetic activity producing side effects such as bradycardia, nasal congestion, dyspepsia and diarrhœea. It also differs in the time taken to produce therapeutic effects which may take as long as six weeks to develop. After a preliminary sedative phase, lasting Io days or so, there follows a stage of 'turbulence' lasting for some three weeks which is then succeeded by anc integrative phase when the patient becomes more co-operative, interested and friendly with relief $\stackrel{+}{\rightleftharpoons}$ of symptoms.

Reserpine and related alkaloids are valuable in $\vec{\circ}$ controlling overactive and disturbed behaviour in schizophrenia and other psychiatric disorders, but $_{c}{ }_{\vec{C}}$ have now been superseded for this purpose by the phenothiazine drugs which produce clinical effects more quickly and reliably.

A serious complication of reserpine therapy $\phi_{0} \overrightarrow{0}$ the development of a severe depressive state whieh may carry the risk of suicide and may need electre convulsive therapy.

Tetrabenazine is a new synthetic drug with an action similar to reserpine. There is some evidence that it may be of value in treating chronic schizo- $\frac{\circ}{\Phi}$ phrenia.

\section{Phenothiazine Derivatives}

Table I lists the most commonly used phenothiazine derivatives. They are mainly in three groups: (I) the dimethylamine series, (2) the piperidine series and (3) the piperazine series.5. Differences in chemical structure, which are 3 . mainly achieved by substitutions at $\mathrm{R}_{\mathrm{I}}$ and $\mathrm{R}_{2}$, are associated with marked differences in potency, clinical activity and toxicity.

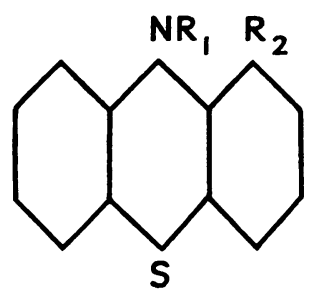

Substitutions at $R \mathrm{I}$. Three main side chains are concerned as substituents at $\mathrm{R}_{\mathrm{r}}$ :

(I) Dimethylamine.

(2) Piperidine. 
TABLE I

\begin{tabular}{|c|c|c|c|c|c|c|c|c|c|c|c|c|c|c|}
\hline \multirow[b]{2}{*}{$\begin{array}{l}\text { Generic } \\
\text { Name }\end{array}$} & \multirow[b]{2}{*}{$\begin{array}{c}\text { Trade } \\
\text { Name(s) }\end{array}$} & \multirow{2}{*}{\multicolumn{2}{|c|}{$\begin{array}{c}\text { Daily Dosage } \\
\text { (mg.) } \\
\text { Low } \\
\text { High }\end{array}$}} & \multicolumn{4}{|c|}{ Side-effects } & \multicolumn{5}{|c|}{$\begin{array}{l}\text { Toxic and } \\
\text { Hyper- } \\
\text { sensitivity } \\
\text { Effects }\end{array}$} & \multirow[b]{2}{*}{$\begin{array}{l}\text { Principal } \\
\text { Indications }\end{array}$} & \multirow[b]{2}{*}{$\begin{array}{l}\text { Limitation and } \\
\text { Disadvantages }\end{array}$} \\
\hline & & & & 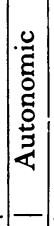 & 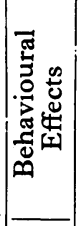 & 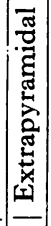 & 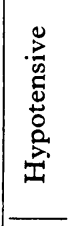 & - & 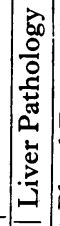 & 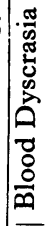 & : & 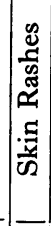 & & \\
\hline $\begin{array}{l}\text { 1. Dimethyla } \\
\text { Chlorpro- } \\
\text { mazine }\end{array}$ & $\begin{array}{l}\text { amine series } \\
\text { Largactil } \\
\text { Thorazine }\end{array}$ & 75 & $\mathrm{I}, \infty 00$ & + & + & + & + & + & -1 & + & & + & $\begin{array}{l}\text { Overactivity, dis- } \\
\text { turbed behaviour } \\
\text { in schizophrenia. } \\
\text { Acute and chronic } \\
\text { organic mental state } \\
\text { (mental defectives } \\
\text { and disturbed chil- } \\
\text { dren). }\end{array}$ & $\begin{array}{l}\text { Little use for anxiety } \\
\text { states. Limited } \\
\text { value for inert and } \\
\text { apathetic schizo- } \\
\text { phrenia. }\end{array}$ \\
\hline $\begin{array}{c}\text { 2. Trifluo- } \\
\text { promazine }\end{array}$ & Vespral & 20 & 150 & + & + & + & + & + & + & + & + & + & As above. & As above. \\
\hline $\begin{array}{c}\text { 3. Lævo- } \\
\text { promazine }\end{array}$ & Verachi & 25 & 700 & + & + & + & ++ & + & \pm & \pm & & + & $\begin{array}{l}\text { As above - greater } \\
\text { sedative action. }\end{array}$ & $\begin{array}{l}\text { Markedly hypoten- } \\
\text { sive. }\end{array}$ \\
\hline $\begin{array}{l}\text { 4. Prothi- } \\
\text { pendyl }\end{array}$ & Tolnate & 40 & 120 & 0 & \pm & 0 & \pm & $\circ$ & 0 & ० & 0 & \pm & $\mid \begin{array}{l}\text { Anxiety states. To } \\
\text { facilitate sleep by its } \\
\text { sedative action or to } \\
\text { potentiate hyp- } \\
\text { notics. }\end{array}$ & $\begin{array}{l}\text { Value in schizo- } \\
\text { phrenia not estab- } \\
\text { lished. }\end{array}$ \\
\hline $\begin{array}{l}\text { 5. Piperazin } \\
\text { Prochlor- } \\
\text { perazine }\end{array}$ & $\begin{array}{l}\text { ne series } \\
\text { Ctemetil } \\
\text { Compazine }\end{array}$ & I 5 & 100 & + & + & + & + & + & \pm & & 0 & + & $\begin{array}{l}\text { Vomiting, tinnitus, } \\
\text { prevention of mi- } \\
\text { graine. Schizo- } \\
\text { phrenia, including } \\
\text { inert and apathetic } \\
\text { patients. }\end{array}$ & $\begin{array}{l}\text { Dystonic reaction in } \\
\text { higher doses. }\end{array}$ \\
\hline $\begin{array}{l}\text { 6. Perphen- } \\
\text { azine }\end{array}$ & Fentazin & 6 & 64 & + & + & + & + & + & \pm & \pm & + & + & $\begin{array}{l}\text { Schizophrenia. Dis- } \\
\text { turbed behaviour in } \\
\text { psychiatric and } \\
\text { physical disease. }\end{array}$ & $\begin{array}{l}\text { Dystonic reaction in } \\
\text { higher doses. }\end{array}$ \\
\hline $\begin{array}{l}\text { 7. Thio- } \\
\text { propazate }\end{array}$ & Dartalan & 15 & 150 & + & + & + & \pm & + & 0 & \pm & 0 & + & $\begin{array}{c}\text { Schizophrenia acute } \\
\text { and chronic. Over- } \\
\text { active disturbed be- } \\
\text { haviour in all psy- } \\
\text { chiatric disorders. } \\
\text { Management of } \\
\text { Huntingdon's cho- } \\
\text { rea. Little or no dan- } \\
\text { ger of liver damage. }\end{array}$ & $\begin{array}{l}\text { More effective and } \\
\text { safer than chlorpro- } \\
\text { mazine. }\end{array}$ \\
\hline $\begin{array}{l}\text { 8. Flu- } \\
\text { phenazine }\end{array}$ & $\begin{array}{l}\text { Moditen } \\
\text { Permtil } \\
\text { Prolixin }\end{array}$ & 0.5 & 10 & + & + & + & + & \pm & + & + & + & + & $\begin{array}{l}\text { Mainly for prevent- } \\
\text { ing anxiety and } \\
\text { tension. }\end{array}$ & $\begin{array}{l}\text { Extrapyramidal side- } \\
\text { effects frequent. }\end{array}$ \\
\hline $\begin{array}{l}\text { 9. Trifluo- } \\
\text { perazine }\end{array}$ & Stelazine & 3 & 30 & + & + & + & \pm & + & \pm & \pm & 0 & + & $\begin{array}{l}\text { All types of schizo- } \\
\text { phrenia. Low doses } \\
\text { for anxiety symp- } \\
\text { toms. }\end{array}$ & $\begin{array}{l}\text { Extrapyramidal side- } \\
\text { effects frequent. }\end{array}$ \\
\hline $\begin{array}{l}\text { ro. Piperidine } \\
\text { Pecazine }\end{array}$ & $\begin{array}{l}\text { e series } \\
\text { Pacatal }\end{array}$ & 75 & 400 & + & + & $\circ$ & $\circ$ & o & + & + & 0 & $\circ$ & $\begin{array}{l}\text { Relief of tension and } \\
\text { anxiety in neuroses. } \\
\text { Reports on thera- } \\
\text { peutic efficiency are } \\
\text { conflicting. }\end{array}$ & $\begin{array}{l}\text { Side-effects more un- } \\
\text { pleasant than chlor- } \\
\text { promazine. }\end{array}$ \\
\hline $\begin{array}{l}\text { I1. Thiori- } \\
\text { dazine }\end{array}$ & Melleril & 30 & 600 & + & + & + & + & + & + & + & + & + & $\begin{array}{l}\text { As tranquilosedative } \\
\text { in neuroses and psy- } \\
\text { choses. }\end{array}$ & Side-effects frequent. \\
\hline
\end{tabular}


(3) Piperazine. This side chain gives increased potency but a greater tendency to increased alertness and to induce extrapyramidal phenomena.

Substitutions at $R \mathbf{2}$ are mainly by such radicals as halogens, methoxy and methyl groups.

The presence of a chlorine atom is directly related to the tendency to produce jaundice in chlorpromazine. Promazine carries no danger of jaundice but is only one third as potent as chlorpromazine. Fluorine, on the other hand, conveys higher potency than chlorine.

The various phenothiazine derivatives differ in clinical effects such as their potency in achieving tranquillization and sedation and their effects on alertness. They all potentiate the effects of central nervous system depressants such as alcohol, anæsthetics, hypnotics, sedatives and narcotics. In varying degrees they are anti-emetic, antihistamine, hypotensive, vagolytic and sympatholytic.

The piperazine derivatives are of higher potency than chlorpromazine and have greater tendency to promote alertness but also a greater tendency to produce extrapyramidal side effects.

Side-effects, toxic and hypersensitivity reactions. It is necessary to distinguish side effects from toxic and hypersensitivity reactions. Side-effects can occur in everyone if the dose is increased sufficiently but toxic and hypersensitivity reactions only affect a proportion of persons and their occurrence is not closely dependent on dosage.

\section{Chlorpromazine}

Chlorpromazine has a variety of interesting pharmacological effects and clinical applications. It is a central nervous system depressant with little action on the cerebral cortex but selective actions on certain cortical structures and on both central and peripheral parts of the autonomic nervous system. It has hypotensive, sympatholytic, vagolytic and weak antihistamine activity, as well as anti-emetic properties, and potentiates the effect of sedatives and narcotics and anæsthetics.

Chlorpromazine has stood the test of time and is a reliable drug for the treatment of disturbed behaviour, tension and excitement and overactivity in schizophrenia, hypomania and in organic mental states, such as senile dementia, arterio-sclerotic dementia, etc. in mental defectives and in children with behaviour disorders. Its value in neuroses is limited and it is of little value in the treatment of depressive states apart from the relief from some degree of tension and anxiety. In normal and neurotic patients it tends to produce too great a feeling of apathy and indifference and its action in relieving anxiety is variable and unpredictable.

\section{Anti-depression Drugs}

There are three main groups of drugs used for elevation of mood:

(I) Central nervous system stimulants, amphet $\frac{\mathrm{\alpha}}{-}$ mines, pipradol and methyl phenidate.

(2) Monoamine oxidase inhibitors.

(3) Imipramine and chemically allied drugs.

\section{Central Nervous Stimulants}

The really important advance in the pharmacotherapy of depression occurred with the discovefy of iproniazid and imipramine some 4 to 5 years ago.

Prior to this the only agents available were t stimulants which had very limited application and serious disadvantages.

The main indication for the amphetamine drugs is in patients with short-lasting, early morning depression of moderate or mild degrees of severit

The disadvantage of amphetamines include tolerance, dependency and addiction. Shorflasting elevation of mood is followed by post medication increased fatigue, irritability and depression.

\section{Monoamine oxidase Inhibitors}

The finding that reserpine which sometiffes causes depression produces a fall in levee of noradrenaline and serotonin in the central ner. system and that iproniazid raises their level concurrent increased psychomotor activity, pro vided a stimulating hypothesis for resear. workers on biochemical and pharmacotherapeutio aspects of depression.

The work of Kline revealed the value $\overrightarrow{\overrightarrow{\sigma f}}$ iproniazid in treating depressive illnesses. Ipron'iazid has a serious disadvantage in causing tox liver necrosis in some patients which not infrequently proved fatal.

A large series of new monoamine oxidase $i$ : hibitors have subsequently been discovered and used for treating depression.

Some of these have already been withdrawn be cause of toxic effects. The three which have stood the test of time are phenelzine, nialamide, is carboxazid and tranylcypromine.

None of these drugs is as effective as ECT for severe endogenous depression. They are mainfy of value for depressive illnesses of mild or moda erate severity. Data on these drugs are given Table 2.

\section{Imipramine and Other Drugs}

Imipramine is an iminidodibenzyl derivative similar in chemical structure to chlopromazine Little interest was at first taken in this drug as its tranquillizing properties were slight and it w落 only when Kuhn demonstrated its value 
TABLE 2

\begin{tabular}{|c|c|c|c|c|c|c|c|c|c|}
\hline Generic Name & $\begin{array}{l}\text { Trade } \\
\text { Name }\end{array}$ & $\begin{array}{c}\text { Usual Daily } \\
\text { Dosage } \\
\text { Range } \\
\text { (mg.) }\end{array}$ & 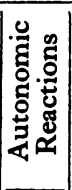 & 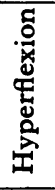 & 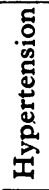 & 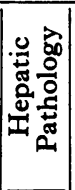 & 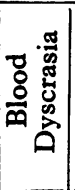 & 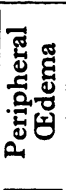 & Other Effects \\
\hline Iproniazid & Marsilid & $5-75$ & + & + & + & + & + & + & \\
\hline Phenelzine & Nardil & $15-75$ & & & & & & & \\
\hline Nialamide & Niamid & $35-300$ & + & + & + & + & + & + & \\
\hline Isocarboxazid & Marplan & $10-30$ & + & + & + & + & + & + & \\
\hline Tranylcypramine & Parnate & $10-30$ & + & + & + & $\circ$ & ○ & $\circ$ & Severe headaches occasionally occur. \\
\hline Imipramine & Tofranil & $25-150$ & + & + & + & + & + & + & $\begin{array}{l}\text { Parkinsonism and skin disorders } \\
\text { may occur. }\end{array}$ \\
\hline Amitryptilene & Tryptyzol & $25-150$ & + & + & + & ० & 0 & 0 & $\begin{array}{l}\text { Dyskinesia and skin disorders may } \\
\text { occur. }\end{array}$ \\
\hline
\end{tabular}

treating depression that its potentialities were recognized. Published reports in the main agree regarding its value in endogenous and reactive depressions. It is not as effective as ECT for the severe endogenous depressions.

The mode of action of imipramine is not freely understood. It is not a monoamine oxidase inhibitor, and does not produce excitation in normal subjects or animals.

Recent studies have provided evidence that the anti-depressive action of imipramine is probably mediated through a metabolic product, viz. a monomethyl analogue. The removal of a methyl group from imipramine results in greater rapidity of anti-depressant action.

Amitryptilene is claimed to be effective in relieving anxiety, tension and agitation and associated depression. Published reports are conflicting regarding its therapeutic value in depressive illnesses.

\section{Anti-anxiety Drugs}

These may be classified into:
(I) Minor tranquillizers.
(2) Tranquilosedatives.
(3) Hyposedatives.

Minor Tranquillizers are central nervous system depressants acting on subcortical structures in diencephalon and midbrain but less marked and more discriminate in action than the major tranquillizers.

The main groups of minor tranquillizers are:

(I) Phenothiazine derivatives such as promazine, promethazine and diethazine.

(2) Benzhydryl derivatives including captodiamine and hydroxyzine.
Promazine is one-third as potent as chlorpromazine but does not carry the risk of jaundice.

It is useful in the management of alcoholic disorders as it does not affect liver function and has calming and anti-emetic actions. It is less hypotensive than chlorpromazine and preferable for treating those elderly people who tend to have syncope with hypotension and postural changes. It also has a place in management of mildly anxious or disturbed ambulant patients attending out-patient clinics or in general practice.

Hydroxyzine has adrenolytic, anticholinergic, anti-emetic, anti-histaminic and anti-spasmodic properties.

Its main use is relief of anxiety, tension and overactivity in neuroses.

Captodiamine has anti-histaminic, anti-emetic and some sedative effects. Clinical trials have failed to establish its therapeutic value as a tranquillizer.

Tranquilosedatives differ from the tranquillizing drugs in having no significant action on the autonomic nervous system. They are central nervous system depressants acting on polysynaptic spinal pathways. Extrapyramidal symptoms do not occur and in contrast to major tranquillizers they increase the threshold to convulsions.

Meprobamate was developed from myanesin, a muscle relaxant. Its main use is the treatment of neuroses for relief of anxiety and tension, particularly when associated with increased muscular tension.

When given in high doses over a long period tolerance and withdrawal symptoms may occur and therefore the risk of addiction.

Methaminodiazepoxide (Librium) has calming 
properties without inducing sleep. It is anticonvulsant and a muscular relaxant and stimulates appetite. Its main indications are in neuroses for the relief of anxiety, distress, phobias and symptoms due to increased muscular tension.

It is also given with antidepressants to alleviate anxiety associated with depression. A number of new derivatives, analogues of Librium, have been produced and some are promising but not yet on the market.

\section{Hypnosedatives}

These are depressants of the cerebral nervous system which reduce spontaneous activity and which in large doses produce ataxia leading to hypnosis and in higher doses still, anæsthesia. They are used as hypnotics and some in lower doses as daytime sedatives.

Among the barbiturates amylobarbitone in doses of $\frac{3}{4}$ to $1 \frac{1}{4}$ grs. three times daily is reliable and effective for the relief of anxiety and tension? Among non-barbiturate hypnosedatives, glutethi mide is a safe hypnotic and daytime sedative.

Methyl pentynol is effective in allaying appre hension in a variety of situations. Toxic reaction $\overline{\vec{\beta}}$ are frequent and consist of drowsiness, ataxiao dysarthria, diplopia, nystagmus and tremors. The carbamate derivative has longer duration of actio $\bar{p}$ and less toxic and side effects.

\section{Conclusions}

The discovery of new drugs in the past decad $\vec{P}$ has revolutionized psychiatric treatment. Further $\vec{r}$ advances can be expected. The need for carefuw testing and screening and fully controlled clinicas trials before new drugs are marketed is at las $\bar{E}$. becoming recognized and, when fully implesis mented, will accelerate progress in this important field of treatment for the most distressing illnesses which afflict mankind. 